\title{
Changing roles of propagule, climate, and land use during extralimital colonization of a rose chafer beetle
}

\author{
Jakub Horak • Cang Hui • Núria Roura-Pascual • \\ Dusan Romportl
}

Received: 25 October 2012 /Revised: 26 February 2013 /Accepted: 27 February 2013 / Published online: 20 March 2013

(C) Springer-Verlag Berlin Heidelberg 2013

\begin{abstract}
Regardless of their ecosystem functions, some insects are threatened when facing environmental changes and disturbances, while others become extremely successful. It is crucial for successful conservation to differentiate factors supporting species' current distributions from those triggering range dynamics. Here, we studied the sudden extralimital colonization of the rose chafer beetle, Oxythyrea funesta, in the Czech Republic. Specifically, we depicted the range expansion using accumulated historical records of first known occurrences and then explained the colonization events using five transformed indices depicting changes in local propagule pressure (LPP), climate, land use, elevation, and landscape
\end{abstract}

Communicated by: Sven Thatje

Electronic supplementary material The online version of this article (doi:10.1007/s00114-013-1029-2) contains supplementary material, which is available to authorized users.

\section{J. Horak $(\triangle)$}

Faculty of Forestry and Wood Sciences,

Czech University of Life Sciences Prague, Kamycka 1176,

16521 Prague 6, Czech Republic

e-mail: jakub.sruby@gmail.com

C. Hui

Centre for Invasion Biology, Department of Botany and Zoology, Stellenbosch University, Matieland 7602, South Africa

\section{N. Roura-Pascual}

Àrea de Biologia Animal, Departament de Ciències Ambientals, Facultat de Ciències, Universitat de Girona, Campus Montilivi, 17071 Girona, Catalonia, Spain

\section{N. Roura-Pascual}

Landscape Ecology Laboratory, Centre Tecnològic Forestal

de Catalunya, Crta. de Sant Llorenc de Morunys Km. 2,

25280 Solsona, Catalonia, Spain

\section{Romportl}

Department of Physical Geography and Geoecology, Faculty of Sciences, Charles University, Albertov 6, 12843 Prague, Czech Republic structure. The slow occupancy increase of $O$. funesta before 1990 changed to a phase of rapid occupancy increase after 1990 , driven not only by changes in the environment (climate and land use) but also by the spatial accumulation of LPP. Climate was also found to play a significant role but only during the niche-filling stage before 1990, while land use became important during the phase of rapid expansion after 1990. Inland waters (e.g., riparian corridors) also contributed substantially to the spread in the Czech Republic. Our method of using spatially transformed variables to explain the colonization events provides a novel way of detecting factors triggering range dynamics. The results highlight the importance of LPP in driving sudden occupancy increase of extralimital species and recommend the use of LPP as an important predictor for modeling range dynamics.

Keywords Climate change Local propagule pressure . Occupancy $\cdot$ Oxythyrea funesta $\cdot$ Population dynamics and establishment $\cdot$ Riparian corridors

\section{Introduction}

Human-mediated changes in climate and land use can have profound effects on species' survival and distribution (Lepers et al. 2005; Thomas et al. 2004; Both et al. 2006; Roura-Pascual et al. 2011). While most species are dwindling due to these changes - especially specialists or rare species, others behave rather robustly with some even thriving in the novel environment created by these changes (Samways 2007). Indeed, many introduced and indigenous species, which were previously constrained by dispersal and ecological barriers, have been reported to rapidly change the distributional structures of their novel or historical ranges (e.g., undergoing rapid range expansion; Richardson and Pyšek 2006; Konvicka et al. 2003; Roura-Pascual et al. 2009). It is, thus, crucial for any 
successful conservation effort to examine what factors trigger and drive the dynamics of species occupancy and distribution (i.e., expansion or retraction; Lockwood et al. 2005; Soberón and Peterson 2005).

The extralimital colonization of many indigenous species, to this end, provides an ideal natural experiment for clarifying the triggers and drivers of the rapid spread of those species with a previously rather static distribution. Compared to many invasive alien species whose range expansion represents the process of filling existent empty niches (Lockwood 1993; Ricklefs 2010), extralimital species (i.e., domestic exotics) can colonize either by filling novel niches created by environmental changes (Guo and Ricklefs 2010) or outburst due to accumulating local propagule pressure (LPP; i.e., the accumulation of individuals dispersed from viable surrounding populations determines the colonization success of an empty habitat; Lockwood et al. 2005). We, therefore, expect to identify both habitat characteristics and LPP as important drivers of extralimital colonization.

As a species-rich taxon with important ecosystem functions, insects often respond to environmental changes in various ways (Samways 2007; Horák et al. 2012). Some insect species become enormously successful when facing environmental changes and take great advantage of habitats created by changes in climate (Parmesan 2006; Rosenzweig et al. 2008) and land use (Zimmermann et al. 2005). Some habitat specialists and other endangered fauna can even thrive in highly disturbed habitat remnants (Beneš et al. 2003; Tropek et al. 2010; Lenda et al. 2012). This leads to a common phenomenon that retracting species are often associated with, although not necessarily caused by, expanding extralimital species in human-modified environments.

To date, quantitative studies on the role of LPP during a sudden and rapid colonization event of a rare species are lacking. We here examine both the buildup of LPP and environmental gradients that could potentially drive the sudden extralimital colonization of the rose chafer beetle Oxythyrea funesta (Poda 1761; Coleoptera: Scarabaeoidea: Cetoniidae), an important pollinator at adulthood and scavenger at larval stage. Besides its widespread Palearctic distribution, O. funesta has been considered rare and near extinction in the Czech Republic (Král 1989). We propose a unique way to quantify LPP and its role in triggering the sudden fast colonization of $O$. funesta in the last decades. Specifically, we first identify the transition time between the slow and fast phases of extralimital colonization and then seek for key drivers of colonization among LPP and environmental factors for both before and after the transition time. Our study, thus, highlights the changing role of environmental factors at different stages of colonization.

\section{Materials and methods}

Study species and area

Eleven species are known from the genus Oxythyrea Mulsant 1842 . The rose chafer beetle $O$. funesta is the only species that distributes throughout Europe and partly in northern Africa and Asia (Smetana 2006). It has a 1-year development time, with larvae developing in decaying residues and overwintering adults feeding on pollens of many plant species. This species has been considered a rare thermophilic relict of postglacial steppes occurring in scattered patterns on xeric localities in most central European localities (Horion 1958; Burakowski et al. 1983), although it has recently undergone a sudden colonization and thus become an extralimital invader (Guo and Ricklefs 2010).

We here study the colonization event of $O$. funesta in the Czech Republic under temperate continental climate (Tolasz 2007). This central European country has recently started to experience rising temperatures and changing rainfall patterns (Kyselý 2004; Dubrovský et al. 2005) and also witnessed a dramatic change in land cover after World War II when socialist industrialization (1948-1989) gradually transformed large extensions of grasslands into agricultural land and subsequently into industrial zones (Krahulec et al. 2001). This trend of land use changes has been further altered since the Velvet Revolution in 1989 when the use of fertile land started to intensify due to the competition of Czech agriculture and forestry with other EU states, with unproductive areas gradually being converted back to grasslands or commercial forests (Bičík et al. 2001).

\section{Occurrence and environmental data}

Species occurrence data in the study area were excerpted from published sources (Table S1) and an online database (Chobot and Horák 2012; $n=675$ records from 1819 to 2010). All data were mapped in the rectangular Central European grid cell system, with a resolution of $10^{\prime}$ longitude by $6^{\prime}$ latitude (equivalent to $11.1 \times 12 \mathrm{~km}$ ) and a total of 676 grid cells in the Czech Republic (Fig. 1). Occurrence data were not derived from an annual systematic survey (see Rocchini et al. 2011), so most grid cells recorded the presence of the species more than once within 1 year or for multiple years. For grid cells with more than one record of presence, we used the oldest records to represent the first occurrence $(n=299)$.

These records of first occurrences were then used (1) to detect the transition time of the two-phase colonization (a slow occupancy increase followed by a fast increase) by plotting the occupancy based on first occurrences over time and (2) to identify key factors driving the colonization at different phases (i.e., for the slow and fast colonization periods, respectively) by means of a multivariate analysis. 

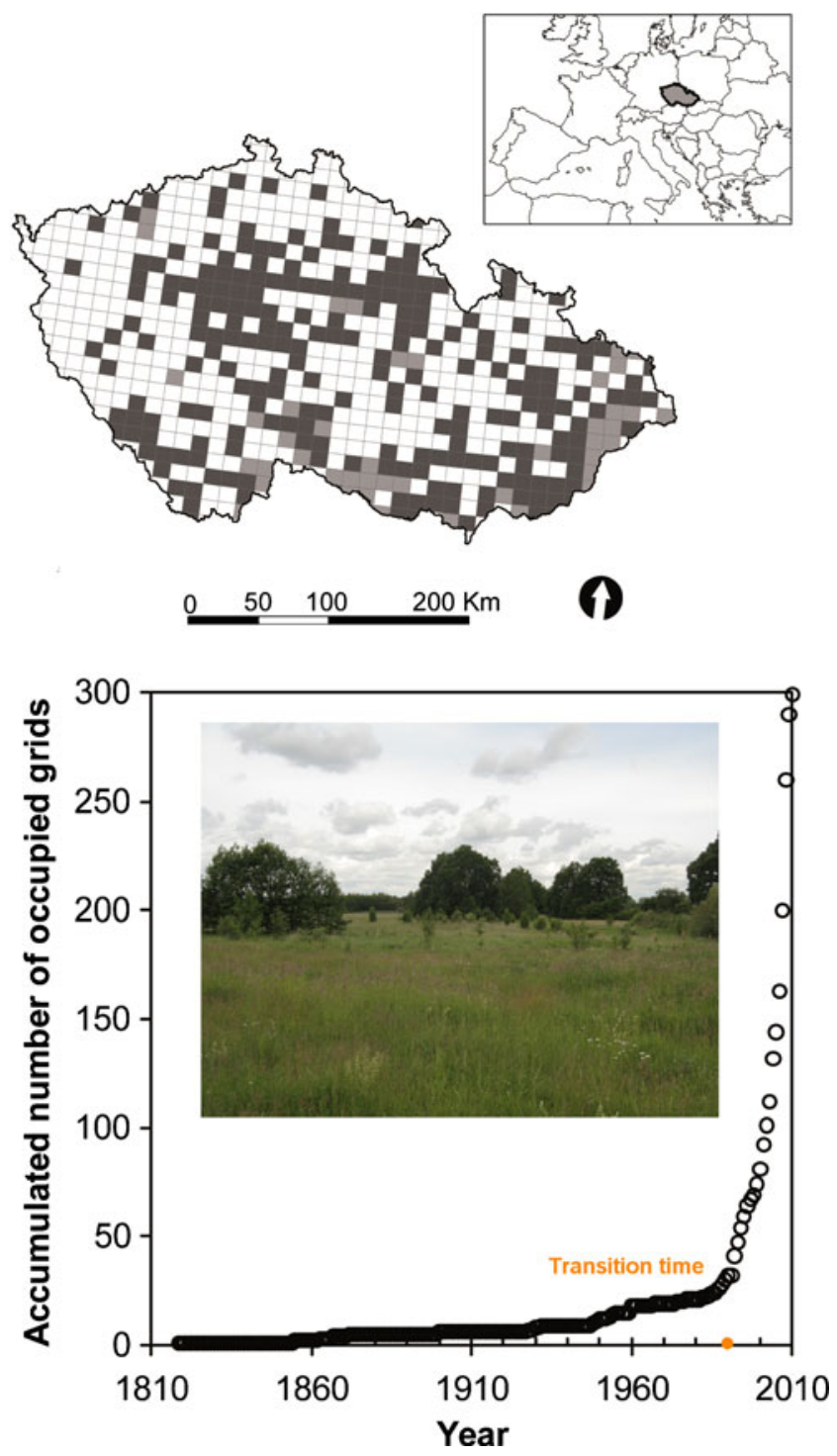

Fig. 1 Distribution and range expansion of the rose chafer beetle $O$. funesta in the Czech Republic. Grid cells on the top map show the occupancy of the species pre-1990 (gray cells) and post-1990 periods (black cells). The bottom graph presents the accumulated number of presence records from 1810 to 2010, with the orange dot indicating the transition time. The picture illustrates a typical riparian habitat (along river Tichá Orlice and between two ponds Velký and Malý Karlov) colonized by $O$. funesta

For the selection of key drivers of expansion, instead of using the above records of first occurrence, we calculated the colonization events of two consecutive decades as the dependent variable. For instance, for the pre-1990 decade, the status of a focal grid cell would be assigned to 1 if it was empty pre-1990 but occupied during 1990 to 2000; the value would be assigned to 0 if it remained empty at least till 2000. We ignored grid cells that were occupied before 1990 as the data is incapable of recording extinction events. Consequently, the dependent variable emphasizes the colonization event at a decadal pace, different from studies that use static presence/absence records as the dependent variable. This new dependent variable was then combined with various environmental variables grouped in five different categories (i.e., propagule pressure, climate, elevation, land use, and landscape structure) that could potentially play a role in explaining the species' extralimital colonization (Tables 1 and S2). Potential effects of sampling biasesdue to unsystematic survey derived records - on the selection of environmental predictors were examined by means of a randomization procedure (described in the "Statistical analyses" subsection).

\section{Data transformation}

Propagule pressure (normally equally introduction effort) plays a key role in structuring natural communities and is also considered a key factor of invasion success (Richardson and Pyšek 2006; Catford et al. 2009; Lawrence and Cordell 2010). It depicts the effect of both the number and rate of incoming individuals dispersed from reachable populations on the colonization success of an empty habitat (Lockwood et al. 2005; Groom et al. 2006). The role of propagule pressure on establishment (i.e., colonization) is often tested using controlled experiments or records from acclimatization societies (Gertzen et al. 2011). We here propose a new way to quantify the LPP that could be important for successful colonization. For a focal grid cell (Fig. S1), we first calculated the number of presences $\left(p_{1}\right)$ and absences $\left(a_{1}\right)$ in the immediately adjacent cells $\left(n_{1}=p_{1}+a_{1} \leq 8\right)$, and then the number of presences $\left(p_{2}\right)$ and absences $\left(a_{2}\right)$ in the secondary neighboring cells $\left(n_{2}=p_{2}+a_{2} \leq 16\right)$. The LPP was then calculated as $\mathrm{LPP}=w_{1}\left(p_{1} / n_{1}\right)+w_{2}\left(p_{2} / n_{2}\right)(0 \leq \mathrm{LPP} \leq 1)$, where $w_{1}$ and $w_{2}$ are weights. Specifically, we chose $w_{1}=2 / 3$ and $w_{2}=1 / 3$ to reflect that closer propagules contribute more to the colonization than propagules further away. Since LPP follows a binomial distribution, we performed a Logit transformation (Logit $(\mathrm{LPP}+0.01))$ in the following analysis. Evidently, this definition not only considers the effect of local propagule size but also the spatial autocorrelation of existing propagules on the colonization of the focal cell.

To account for both the habitat preference of $O$. funesta and the spatial autocorrelation of environmental variables, we transformed all environmental variables in Table 1 as follows. Let $x$ be the value of a specific variable in the focal grid cell, $x_{0}$ and $x_{1}$ be the mean values of the variable in empty and occupied adjacent cells, respectively; let $x_{3}$ and $x_{4}$ be the mean values of the variable in empty and occupied secondary neighboring cells. If the focal grid cell has been occupied during the period (i.e., the dependent variable is 1), we have the transformed variable $X=w_{1}\left(x-x_{0}\right)+w_{2}\left(x-x_{3}\right)$; if the focal cell remains empty (i.e., the dependent variable is 0 ), we have $X=w_{1}\left(x-x_{1}\right)+w_{2}\left(x-x_{4}\right)$. In this way, we considered both the spatial autocorrelation of the variable and the habitat 
Table 1 Selected predictors, divided into categories and subcategories that potentially affected $O$. funesta occurrences

\begin{tabular}{|c|c|c|}
\hline Categories & Subcategories & Predictors \\
\hline Propagule pressure & & Local propagule pressure \\
\hline Climate & & $\begin{array}{l}\text { Annual mean temperature; mean and maximum summer } \\
\text { temperature; total summer precipitation }\end{array}$ \\
\hline \multirow[t]{5}{*}{ Land use } & Artificial surfaces & Artificial, nonagricultural vegetated areas (i.e., urban greenings) \\
\hline & Agricultural areas & Pastures and meadows; heterogeneous agricultural areas \\
\hline & Forest and seminatural areas & Scrub and/or herbaceous vegetation associations (i.e., seminatural vegetation) \\
\hline & Wetlands & Inland wetlands \\
\hline & Water bodies & Inland waters \\
\hline Elevation & & Mean; minimum; maximum; range and SD of elevation \\
\hline \multirow[t]{4}{*}{ Landscape structure } & Patch density and size metrics & $\begin{array}{l}\text { Number of patches; mean and median patch size; patch size } \\
\text { coefficient of variance and SD }\end{array}$ \\
\hline & Edge metrics & Total edge; edge density; mean patch edge \\
\hline & Shape metrics & $\begin{array}{l}\text { Mean shape index; area weighted mean shape index; mean perimeter-area ratio; } \\
\text { mean patch fractal dimension; area weighted mean patch fractal dimension }\end{array}$ \\
\hline & Diversity and interspersion metrics & Shannon's diversity and evenness indexes \\
\hline
\end{tabular}

preference of the species $(X>0$ indicates that the species prefers to colonize neighboring cells with a higher level of the variable). We then standardized these transformed variables in the following multivariate analyses.

\section{Statistical analyses}

To reduce multicollinearity among predictors, we calculated the variance inflation factors (VIFs; Belsley et al. 1980). The VIFs were computed for predictors in each study period (i.e., a decade before and after the transition time) using the R package $\mathrm{HH}$ (Heiberger and Holland 2004). All predictors with $\mathrm{VIF} \geq 2$ were excluded from forthcoming analyses to avoid biases (Table S2; Graham 2003).

Generalized linear models (GLM) with a binomial distribution and Logit link function were computed for both study periods (decades before and after the transition time) using R (Lindsey 2000). For each period, we examined all model combinations of the finally selected predictors (i.e., 10 predictors, giving 1,023 model combinations) and then selected the best scenario based on the Akaike information criterion (AIC; Quinn and Keough 2002). When several models showed low AIC values, we calculated the difference in AIC values between the best and those models with a lower number of predictors (i.e., $\triangle \mathrm{AIC}$ ). Only models with $\triangle \mathrm{AIC} \leq 2$ received substantial support and were considered when making inferences (Burnham and Anderson 2002). Comparison of reduced deviance between models was computed using analysis of variance (ANOVA) with a chi-square distribution. If $\triangle \mathrm{AIC}$ did not drop significantly $(P>0.05)$, then we chose the model with fewer variables (Lindsey 2000). The same method was used to compare the final GLMs with the null model without any predictors (Šmilauer 2007).
In order to determine the variance explained of predictors in the final model, we applied a hierarchical partitioning method (Chevan and Sutherland 1991) using the R package hier.part (Walsh and MacNally 2003). The method of hierarchical partitioning can assess (1) independent contribution of a predictor, which is explained by the predictor itself exclusively; (2) joint contribution, which is shared with all other predictors; (3) total variance explained, which is a sum of the joint and independent contributions of each predictor; and (4) percentage of total variance explained, which gives the percentage of each predictor's total variance explained with respect to the sum of all predictors' total variance explained. A predictor with a negative joint contribution indicates that other predictors act as suppressors on the particular predictor (Walsh and MacNally 2003).

We applied a randomization procedure to examine the effect of potential sampling biases from nonsystematic surveys (Dennis et al. 1999) of O. funesta on the selection of key factors in the multivariate analyses. Specifically, a few years could have elapsed between the actual colonization and the detection of $O$. funesta (i.e., the first occurrence record) in a focal grid cell, and the time elapse between colonization and detection depends on multiple factors related to sampling effort and accessibility of the grid cell. For simplicity, we generated a random time elapse for each colonized grid cell following a Poisson distribution with a mean of 2 years. As currently absent cells could represent either nondetected pseudo-absences due to insufficient sampling effort or true absences (Hui et al. 2011), we chose a proportion of $5 \%$ pseudo-absences and assigned these cells with the first occurrence year randomly selected from current colonized cells. We then performed the hierarchical partitioning for 1,000 runs following the previously 
described randomization procedure, with each run including random corrections of the first occurrence year for both colonized and pseudo-absent cells.

\section{Results}

The accumulated records of first occurrences indicate a transition time from a slow increase of occupancy to a fast one around 1990, indicating a two-phase extralimital colonization event (Fig. 1). O. funesta occupied 32 grid cells till 1990 (with a $2 \%$ annual increase of its occupancy), but then experienced a rapid occupancy increase and colonized another 48 new grid cells during the next decade after 1990 (with a $13 \%$ annual increase of its occupancy; Table 2).

Consequently, we examined the changing role of LPP and other environmental variables in the colonization of $O$. funesta during the decade pre-1990 (from 1981 to 1990) and the decade post-1990 (from 1991 to 2000). Of the 31 environmental variables initially considered, 21 predictors were excluded due to multicollinearity (Table S2). Annual mean temperature was also excluded from the post-1990 GLM to facilitate comparisons with the pre-1990 model. The accuracy of this exclusion was confirmed using an ANOVA with a chi-square distribution, which did not show significant differences between the post-1990 GLMs with and without annual mean temperature $(d f=5$; $\mathrm{AIC}=774.3 ; P=0.70)$. Most predictors included in the final analyses had a nonsignificant effect on the colonization.

During the pre-1990 decade (1981-1990), the colonization of $O$. funesta was facilitated by LPP, mean summer temperature, and area of inland waters. During the post1990 decade (1991-2000), the colonization was positively driven by LPP, area of inland waters, and area of urban greenings (Table 3). The final selected models contained three predictors (Table S3) that had a significant and positive contribution in explaining the range expansion of $O$. funesta in both periods (Table 4) and one (seminatural vegetation) with negative contribution in the post-1990 period.

The results of the hierarchical partitioning of the final pre-1990 GLM showed that the independent contributions of the three predictors (LPP, mean summer temperature, and area of inland waters), expressed as proportions of total variance explained, were nearly the same. All predictors also shared low joint contribution to the proportion of variance explained ( $\Sigma<0.4 \%$; Fig. 2a). After 1990, the independent contribution of LPP rose nearly four times with respect to the previous period. The explained variance of area of inland waters was also much higher. The area of urban greenings had the highest independent contribution, while the joint contribution was higher for all land use predictors (area of inland waters, seminatural vegetation, and urban greenings). The joint contribution of LPP was extremely low and moved from positive to negative after 1990, indicating that land use predictors could act as weak suppressors (Fig. 2b).

We did not find any notable effects of potential sampling biases and uncertainty on the contribution of variables in the best selected GLM to the variance explained (as shown in Fig. 2) as, evidently, independent contribution of each variable in the best selected GLM was located within the $95 \%$ confidence interval from 1,000 runs of the randomization test (Table S4), suggesting that our results are robust.

\section{Discussion}

Our study provides the first evidence of the population revival of $O$. funesta in Central Europe and how it has become one of the most common beetles in the region. The species experienced a two-phase extralimital colonization process-i.e., slow increase in occupancy until 1990, followed by a rapid increase in the next decade. Divergences in the rate of colonization pre-1990 and post-1990 respond to changes in the relevance of environmental variables. The best selected GLM explained merely $10.6 \%$ variance of the colonization pre-1990, in contrast to $74.3 \%$ variance explained post-1990 (Table 4), suggesting that our proposed method for data transformation is especially suitable for those species that experience fast changes in occupancy. The low variance explained for the early phase (pre-1990) could suggest that environmental tolerance and humanmediated dispersal played more important roles during the slow colonization than density-dependent propagule pressure and habitat preference.

Local propagule pressure

The extralimital colonization of $O$. funesta was clearly driven by the buildup of LPP, which has been long regarded as

Table 2 Summary statistics of transition time analysis with respect to the occurrence of $O$. funesta in the Czech Republic

\begin{tabular}{llllll}
\hline Period & $Y$ & $R^{2}(\%)$ & $F$ & $P$ & ${\text { Increase rate }\left(\mathrm{yr}^{-1}\right)}^{1}$ \\
\hline Pre-1990 & $\exp (-39.67+0.022 \times$ year $)$ & 95.0 & $3,044.50$ & $<0.01$ & 1.02 \\
Post-1990 & $\exp (-242.04+0.124 \times$ year $)$ & 97.0 & 541.70 & $<0.01$ & 1.13 \\
\hline
\end{tabular}

Significant $P$ values appear in italics 
Table 3 Summary results of the full GLMs explaining the distribution of $O$. funesta for the pre-1990 and post-1990 periods

\begin{tabular}{|c|c|c|c|c|c|c|c|c|}
\hline \multirow[t]{2}{*}{ Predictor } & \multicolumn{4}{|c|}{ Pre-1990 period } & \multicolumn{4}{|c|}{ Post-1990 period } \\
\hline & Estimate & SE & $Z$ & $P$ & Estimate & SE & $Z$ & $P$ \\
\hline Intercept & -1.25 & 0.54 & -2.33 & 0.02 & 0.70 & 0.27 & 2.65 & $<0.01$ \\
\hline Local propagule pressure & 0.44 & 0.16 & 2.77 & 0.01 & 0.44 & 0.08 & 5.33 & $<0.01$ \\
\hline Mean summer temperature & 0.36 & 0.16 & 2.33 & 0.02 & -0.02 & 0.09 & -0.16 & 0.87 \\
\hline Urban greenings & 0.16 & 0.10 & 1.61 & 0.11 & 0.98 & 0.21 & 4.65 & $<0.01$ \\
\hline Pastures and meadows & -0.02 & 0.19 & -0.09 & 0.93 & -0.09 & 0.10 & -0.94 & 0.35 \\
\hline Heterogeneous agricultural areas & 0.04 & 0.17 & 0.26 & 0.80 & 0.04 & 0.10 & 0.37 & 0.71 \\
\hline Seminatural vegetation & 0.07 & 0.20 & 0.38 & 0.70 & -0.30 & 0.14 & -2.17 & 0.03 \\
\hline Inland wetlands & 0.16 & 0.12 & 1.27 & 0.20 & 0.11 & 0.10 & 1.15 & 0.25 \\
\hline Inland waters & 0.25 & 0.11 & 2.24 & 0.03 & 0.61 & 0.15 & 3.99 & $<0.01$ \\
\hline Mean perimeter-area ratio & -0.11 & 0.29 & -0.38 & 0.71 & -0.36 & 0.25 & -1.44 & 0.15 \\
\hline Mean patch fractal dimension & -0.03 & 0.21 & -0.12 & 0.90 & -0.01 & 0.13 & -0.10 & 0.92 \\
\hline AIC value & 319.97 & & & & 689.89 & & & \\
\hline
\end{tabular}

Significant $P$ values appear in italics and only predictors with $\mathrm{VIF}<2$ were included

essential for establishing new colonies (MacArthur and Wilson 1967). If we divide the revival of $O$. funesta in the studied area into different invasion stages (transport, introduction, establishment, and spread; sensu Blackburn et al. 2011), the pre-1990 period can be considered as establishment and the post-1990 period can be considered as spread. Although propagule pressure has been considered a key factor for establishment success (Lockwood et al. 2005; Simberloff 2009), we here presented the first evidence of an even stronger effect of LPP on the last invasion stage (spread) of an extralimital species (or a domestic exotic species; Guo and Ricklefs 2010). The enhanced effect of LPP not only reaffirms the importance of propagule pressure in driving successful biological invasions, but also indicates the buildup of LPP to above certain thresholds as triggers for fast colonization and range expansion.

\section{Climate change}

Like most other flower-visiting rose chafers, O. funesta is a typical member of thermophilic fauna of Central Europe (Horion 1958; Balthasar 1956). It is, thus, not surprising that the mean summer temperature as an expression of ambient energy contributes to the climatic niche of the species. During the early phase of extralimital colonization before 1990, the species preferred to colonize those empty sites with high niche suitability. However, this effect of climate preference dwindled during the stage of fast colonization post-1990. As more suitable areas are being filled up at the fast colonization stage, the climate niche gradient between empty and colonized cells starts to disappear; consequently, this niche preference becomes undetectable (Ricklefs 2010). Although the future distribution of

Table 4 Summary results of the best selected GLMs explaining the distribution of $O$. funesta in the pre-1990 and post-1990 using an AIC selection procedure

\begin{tabular}{|c|c|c|c|c|c|c|c|c|c|c|}
\hline \multirow[t]{2}{*}{ Predictor } & \multicolumn{5}{|c|}{ Pre-1990 period } & \multicolumn{5}{|c|}{ Post-1990 period } \\
\hline & Estimate & SE & $Z$ & TVE & $P$ & Estimate & SE & $Z$ & TVE & $P$ \\
\hline Intercept & -1.32 & 0.53 & -2.47 & - & 0.01 & 0.69 & 0.26 & 2.63 & - & $<0.01$ \\
\hline Local propagule pressure & 0.42 & 0.16 & 2.64 & 3.84 & $<0.01$ & 0.44 & 0.08 & 5.47 & 13.26 & $<0.01$ \\
\hline Mean summer temperature & 0.35 & 0.15 & 2.36 & 2.96 & 0.02 & - & - & - & - & - \\
\hline Urban greenings & - & - & - & - & - & 0.99 & 0.21 & 4.72 & 30.39 & $<0.01$ \\
\hline Seminatural vegetation & - & - & - & - & - & -0.29 & 0.13 & -2.24 & 5.66 & 0.03 \\
\hline Inland waters & 0.28 & 0.11 & 2.65 & 3.78 & $<0.01$ & 0.63 & 0.15 & 4.21 & 25.00 & $<0.01$ \\
\hline AIC value & 309.65 & & & & & 681.85 & & & & \\
\hline
\end{tabular}

Significant $P$ values appear in italics

TVE total variance explained (in percent) derived from hierarchical partitioning 
Fig. 2 Results of hierarchical partitioning showing the proportion of variance explained of selected predictors for $O$. funesta during the pre1990 (a) and post-1990 (b) periods. The pie diagrams are the results of the independent contribution of predictors as a proportion of total explained variance (a)

Pre-1990 period

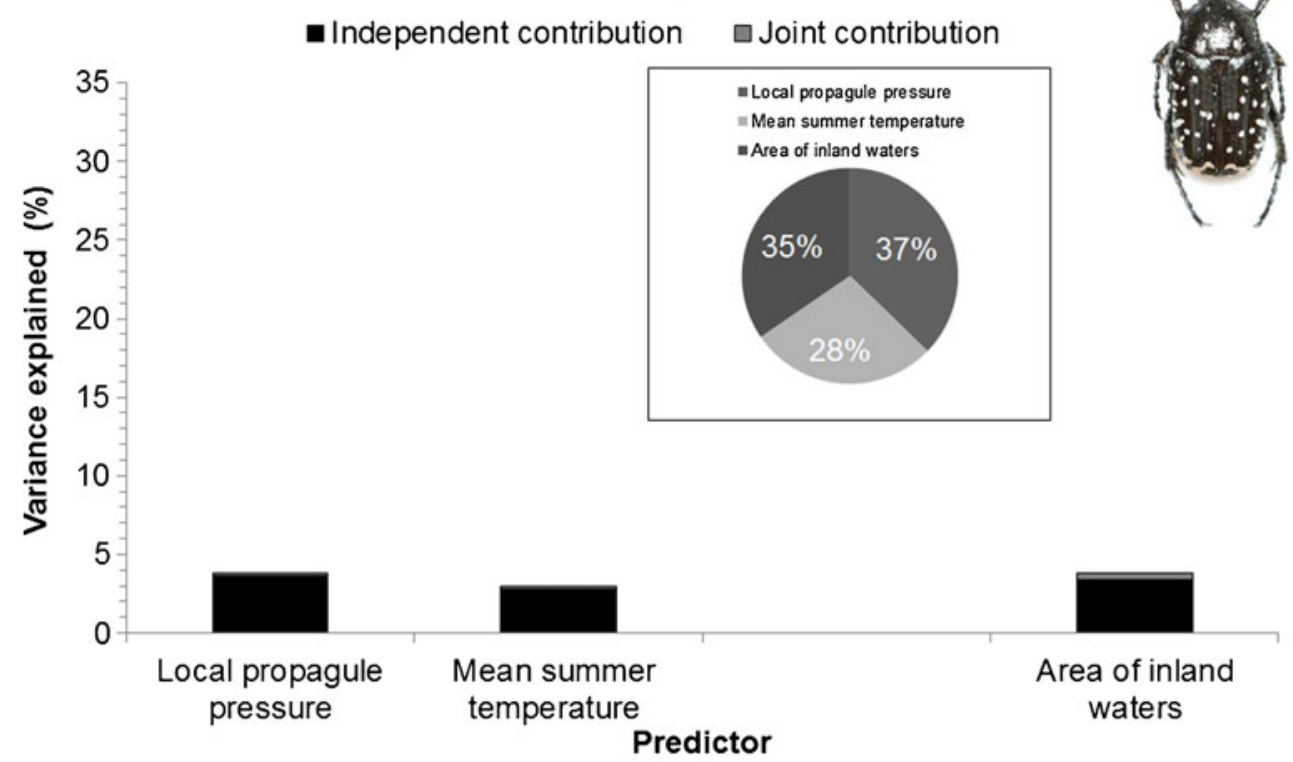

(b)

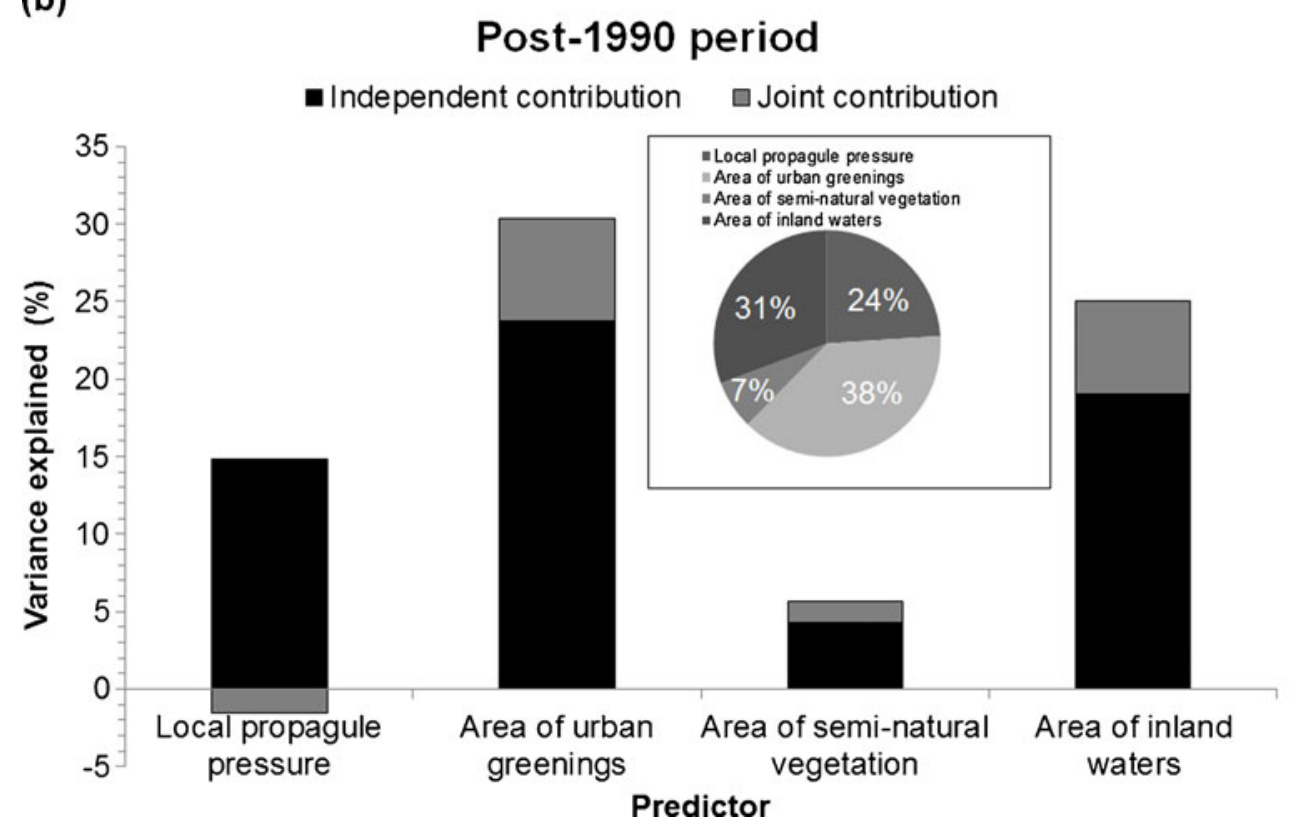

climatically suitable niches of the species is uncertain due to the recent rapid changes in climate (e.g., the gradual rise of the mean summer temperature in the Czech Republic from $15.5^{\circ} \mathrm{C}$ in 1980 to $17.5^{\circ} \mathrm{C}$ in 2000 ; Tolasz 2007), the result here suggests that the climate change will only play a trivial role in the fast extralimital colonization of rose chafer beetles in Central Europe.

\section{Land use}

The colonization of $O$. funesta was consistently facilitated by the existence of large areas of water courses and bodies in both study periods. Although many successful aquatic invaders spread through floods along riparian corridors (Skoglund 1989; Andow et al. 1990; Danvind and Nilsson 1997; Stohlgren et al. 1998), inland waters are often posed as a movement barrier for terrestrial species (see Lomolino et al. 2010 and references therein). Nevertheless, the evidence for terrestrial invertebrates seems to be highly fragmented (see Nève et al. 1996 for threatened butterfly or Ward 1987 for invasive ant). This becomes even more surprising as $O$. funesta was historically reported as relictual to xeric postglacial steppes (Horion 1958; Burakowski et al. 1983). The main reason for consistent effects of inland waters is probably the 
potential increase of flowering plants along the banks and the presence of large amounts of decayed plant debris after floods. Species such as $O$. funesta can benefit from these resources by permitting adults to exploit the pollen of many plants and larvae to feed on decaying plant debris. It is also well-known that riparian corridors are important conservation structures that can facilitate the dispersal of fragmented populations (Fahrig and Merriam 1994). In the case of $O$. funesta, corridors-which fulfill an inherent need for movement (Simberloff et al. 1992) - may have acted as drift fences or greenways (Haddad and Baum 1999; Rosenberg et al. 1997).

Site-level management (e.g., in cities and reserves) often challenges the persistence of many insect taxa (Kadlec et al. 2008; Konvicka et al. 2008); however, our results show that the rose chafer beetles may respond well to intensive management. This is probably due to the positive changes of land use in surroundings (Tscharntke et al. 2002). Urban greenings like parks and gardens are known to host disparate insect communities (McIntyre 2000). The association of $O$. funesta with urban greenings during the rapid colonization suggests that a combination of nectar sources and compost heaps together with plant residues from mulching contributes significantly to the current revival of this species. O. funesta is known to visit many flowering plants and nectar sources from ornamental plants, which are (together with native plants) often used in urban gardens. Urban greenings, thus, keep a more continuous pool of flowers during the whole vegetation season than the natural environments that are more limited by climatic conditions; this is further supported by the negative response of $O$. funesta to the area of seminatural habitats. Furthermore, compost heaps are known to serve as refuges and stepping-stones for arthropods including invaders (Ødegaard and Tømmeras 2000).

\section{Conclusion}

O. funesta, the rose chafer beetle, which was rare in the Czech Republic in the past, is recently undergoing a rapid colonization event and has become one of the most common beetles in Central Europe. Our results suggested that this extralimital invader has shifted to a fast-spread phase after 1990, driven by the buildup of LPP and novel niches created by land use management. The colonization of $O$. funesta was facilitated by high summer temperatures in the slow establishment phase pre1990 but not in the fast-spread phase post-1990. Instead, urban greenings and inland waters became important for fast colonization by providing sufficient food supply for adults and larval development. This is a timely reminder that species distribution modeling, in the framework of environmental changes, should fully acknowledge the changing role of these ecological and environmental factors at different stages of biological invasion.

Changes in the occupancy of a species not only offer the opportunity to elucidate the environmental drivers at play, but also manifest the need to constantly revise the conservation status of species. As the species is conspicuous and can hardly be overlooked (cf. Fisher 2011), the conservation status of $O$. funesta as a rare species in the Czech Republic evidently reflects the situation of the species before 1990 (Král 1989). In light of our findings, we suggest to pay more attention to the actualization of endangered species checklists, especially when they are part of the legal acts.

Acknowledgments We are grateful to Karel Chobot for sharing the data, Jan Wild and Tomáš Chuman for the GIS consulting, Zdeněk F. Fric, Martin Konvička, and Joaquín Hortal for the discussion, Petra Jirmusová for managing the preliminary dataset, Vít Kubáň, Zdeněk Kletečka, and Jiří Šuhaj for the literature search, Ondřej Zika for the interactive space on BioLib, Zdeněk Chalupa for the specimen picture, Eva Chumanová for the preliminary analysis, and special thanks go to the many data collectors. Simone Fattorini and two anonymous referees provided constructive comments. DR is partly supported by institutional resources of the Ministry of the Education, Youth and Sports; JH is partly supported by the Internal Grant Agency (IGA no. 20124364) of the Faculty of Forestry and Wood Sciences, Czech University of Life Sciences Prague; $\mathrm{CH}$ is supported by the NRF Incentive Research Programme and the Elsevier Young Scientist Award; and NRP is supported by the project Consolider Montes (CSD2008-00040) of the Spanish Ministry of Research, Science and Innovation (MICINN).

\section{References}

Andow DA, Kareiva PM, Levin SA, Okubo A (1990) Spread of invading organisms. Landscape Ecol 4:177-188

Balthasar V (1956) Lamellicornia 1-Scarabaeidae-Pleurosticti. Fauna ČSR 8. ČSAV, Praha

Belsley DA, Kuh E, Welsch RE (1980) Regression diagnostics: identifying influential data and sources of collinearity. Wiley, USA

Beneš J, Kepka P, Konvička M (2003) Limestone quarries as refuges for European xerophilous butterflies. Conserv Biol 17:1058-1069

Bičík I, Jeleček L, Štěpánek V (2001) Land-use changes and their social driving forces in Czechia in the 19th and 20th centuries. Land Use Policy 18:65-73

Blackburn TM, Pyšek P, Bacher S, Carlton JT, Duncan RP, Jarošík V, Wilson JRU, Richardson DM (2011) A proposed unified framework for biological invasions. Trends Ecol Evol 26:333-339

Both C, Bouwhuis S, Lessells CM, Visser ME (2006) Climate change and population declines in a long-distance migratory bird. Nature 441:81-83

Burakowski B, Mroczkowski M, Stefańska J (1983) Coleoptera. Scarabaeoidea, Dascilloidea, Byrrhoidea and Parnoidea. Katalog fauny Polski, PWN, Poland

Burnham KP, Anderson DR (2002) Model selection and multi-model inference: a practical information-theoretic approach. Springer, New York

Catford JA, Jansson R, Nilsson C (2009) Reducing redundancy in invasion ecology by integrating hypotheses into a single theoretical framework. Divers Distrib 15:22-40

Chevan A, Sutherland M (1991) Hierarchical partitioning. Am Stat 45:90-96

Chobot K, Horák J (2012) Map of distribution of Oxythyrea funesta in Czech Republic. In: Zicha O (ed) Biological Library-BioLib. Available at http://www.biolib.cz/en/taxonmap/id134/. Accessed 5 April 2012 
Danvind M, Nilsson C (1997) Seed floating ability and distribution of alpine plants along a northern Swedish river. J Veg Sci 8:271-276

Dennis RHL, Sparks TH, Hardy PB (1999) Bias in butterfly distribution maps: the effects of sampling effort. J Insect Conserv 3:33-42

Dubrovský M, Nemesová I, Kalvová J (2005) Uncertainties in climate change scenarios for the Czech Republic. Clim Res 29:139-156

Fahrig L, Merriam G (1994) Conservation of fragmented populations. Conserv Biol 8:50-59

Fisher DO (2011) Cost, effort and outcome of mammal rediscovery: neglect of small species. Biol Conserv 144:1712-1718

Gertzen EL, Leung B, Yan ND (2011) Propagule pressure, Allee effects and the probability of establishment of an invasive species (Bythotrephes longimanus). Ecosphere 2:art30

Graham MH (2003) Confronting multicollinearity in ecological multiple regression. Ecology 84:2809-2815

Groom MJ, Meffe GK, Carroll CR (2006) Principles of conservation biology. Sinauer Associates, Sunderland

Guo Q, Ricklefs RE (2010) Domestic exotics and the perception of invasibility. Divers Distrib 16:1034-1039

Haddad NM, Baum KA (1999) An experimental test of corridor effects on butterfly densities. Ecol Appl 9:623-633

Heiberger RM, Holland B (2004) Statistical analysis and data display: an intermediate course with examples in S-Plus, R, and SAS. Springer, Germany

Horák J, Chobot K, Horáková J (2012) Hanging on by the tips of the tarsi: review of the plight of critically endangered saproxylic beetle in European forests. J Nat Conserv 20:101-108

Horion A (1958) Lamellicornia (Scarabaeidae-Lucanidae). Faunistik der mitteleuropäischen Käfer, vol. 6. A. Feyel, Germany

Hui C, Foxcrof LC, Richardson DM, MacFadyen S (2011) Defining optimal sampling effort for large-scale monitoring of invasive alien plants: a Bayesian method for estimating abundance and distribution. J Appl Ecol 48:768-776

Kadlec T, Benes J, Jarosik V, Konvicka M (2008) Revisiting urban refuges: changes of butterfly and burnet fauna in Prague reserves over three decades. Landscape Urban Plan 85:1-11

Konvicka M, Maradova M, Benes J, Fric Z, Kepka P (2003) Uphill shifts in distribution of butterflies in the Czech Republic: effects of changing climate detected on a regional scale. Global Ecol Biogeogr 12:403-410

Konvicka M, Benes J, Cizek O, Kopecek F, Konvicka O, Vitaz L (2008) How too much care kills species: grassland reserves, agri-environmental schemes and extinction of Colias myrmidone (Lepidoptera: Pieridae) from its former stronghold. J Insect Conserv 12:519-525

Krahulec F, Skálová H, Herben T, Hadincová V, Wildová R, Pecháčková S (2001) Vegetation changes following sheep grazing in abandoned mountain meadows. Appl Veg Sci 4:97-102

Král D (1989) Seznam československých listorohých brouků (Coleoptera, Scarabeoidea). Sb Okr Muz Praha-vých 9:15-30

Kyselý J (2004) Mortality and displaced mortality during heat waves in the Czech Republic. Int J Biometeorol 49:91-97

Lawrence DJ, Cordell JR (2010) Relative contributions of domestic and foreign sourced ballast water to propagule pressure in Puget Sound, Washington, USA. Biol Conserv 143:700-709

Lenda M, Skórka P, Moroń D, Rosin ZM, Tryjanowski P (2012) The importance of the gravel excavation industry for the conservation of grassland butterflies. Biol Conserv 148:180-190

Lepers E, Lambin EF, Janetos AC, Defries R, Achard F, Ramankutty N, Scholes RJ (2005) A synthesis of information on rapid land-cover change for the period 1981-2000. Bioscience 55:115-124

Lindsey JK (2000) Applying generalized linear models. Springer, Germany

Lockwood JA (1993) Benefits and costs of controlling rangeland grasshoppers (Orthroptera: Acrididae) with exotic organisms: search for the null hypothesis. Environ Entomol 22:904-914

Lockwood JL, Cassey P, Blackburn T (2005) The role of propagule pressure in explaining species invasions. Trends Ecol Evol 20:223-228

Lomolino MV, Riddle BR, Whittaker RJ, Brown JH (2010) Biogeography, 4th edn. Sinauer, USA

MacArthur RH, Wilson EO (1967) The theory of island biogeography. Princeton University Press, USA

McIntyre NE (2000) Ecology of urban arthropods: a review and a call to action. Ann Entomol Soc Am 93:825-835

Nève G, Barascud B, Hughes R, Aubert J, Descimon H, Lebrun P, Baguette M (1996) Dispersal, colonization power and metapopulation structure in the vulnerable butterfly Proclossiana eunomia (Lepidoptera: Nymphalidae). J Appl Ecol 33:14-22

Ødegaard F, Tømmeras BA (2000) Compost heaps-refuges and stepping-stones for alien arthropod species in northern Europe. Divers Distrib 6:45-59

Parmesan C (2006) Ecological and evolutionary responses to recent climate change. Annu Rev Ecol Evol S 37:637-669

Quinn GP, Keough MJ (2002) Experimental design and data analysis for biologists. Cambridge University Press, UK

Richardson DM, Pyšek P (2006) Plant invasions: merging the concepts of species invasiveness and community invasibility. Prog Phys Geogr 30:409-431

Ricklefs RE (2010) Evolutionary diversification, coevolution between populations and their antagonists, and the filling of niche space. $\mathrm{P}$ Natl Acad Sci USA 107:1265-1272

Rocchini D, Hortal J, Lengyel S, Lobo JM, Jiménez-Valverde A, Ricotta C, Bacaro G, Chiarucci A (2011) Uncertainty in species distribution mapping and the need for maps of ignorance. Prog Phys Geogr 35:211-226

Rosenberg DK, Noon BR, Meslow EC (1997) Biological corridors: form, function, and efficacy. BioScience 47:677-687

Rosenzweig C, Karoly D, Vicarelli M, Neofotis P, Wu Q, Casassa G, Menzel A, Root TL, Estrella N, Seguin B (2008) Attributing physical and biological impacts to anthropogenic climate change. Nature 453:353-357

Roura-Pascual N, Bas JM, Thuiller W, Hui C, Krug RM, Brotons L (2009) From introduction to equilibrium: reconstructing the invasive pathways of the Argentine ant in a Mediterranean region. Glob Change Biol 15:2101-2115

Roura-Pascual N, Hui C, Ikeda T, Leday G, Richardson D, Carpintero S (2011) The relative roles of climatic suitability and anthropogenic influence in determining the pattern of spread in a global invader. P Natl Acad Sci USA 108:220-225

Samways M (2007) Insect conservation: a synthetic management approach. Annu Rev Entomol 52:465-487

Simberloff D (2009) The role of propagule pressure in biological invasions. Annu Rev Ecol Evol S 40:81-102

Simberloff D, Farr JA, Cox J, Mehlman DW (1992) Movement corridors: conservation bargains or poor investments? Conserv Biol 6:493-504

Skoglund SJ (1989) Seed dispersing agents in two regularly flooded river sites. Can J Botany 68:754-760

Smetana A (2006) Subfamily Cetoniinae. In: Löbl I, Smetana A (eds) Catalogue of Palaeartic Coleoptera, vol 3. Apollo Books, Denmark, pp 283-313

Šmilauer P (2007) Moderní regresní metody. Czech Republic, Biologická fakulta JU

Soberón JM, Peterson AT (2005) Interpretation of models of fundamental ecological niches and species' distributional areas. Biodiv Inform 2:1-10

Stohlgren TJ, Bull KA, Otsuki Y, Villa CA, Lee M (1998) Riparian zones as havens for exotic plant species. Plant Ecol 138:113125 
Thomas CD, Cameron A, Green RE, Bakkenes M, Beaumont LJ, Collingham YC, Erasmus BFN, de Siqueira MF, Grainger A, Hannah L, Hughes L, Huntley B, van Jaarsveld AS, Midgley GF, Miles L, Ortega-Huerta MA, Peterson AT, Phillips OL, Williams SE (2004) Extinction risk from climate change. Nature 427:145-148

Tolasz R (2007) Klimatický atlas Česka. Czech Republic, ČHMÚ

Tscharntke T, Steffan-Dewenter I, Kruess A, Thies C (2002) Characteristics of insect populations on habitat fragments - a mini review. Ecol Res 17:229-239

Tropek R, Kadlec T, Karešová $P$, Spitzer L, Kočárek $P$, Malenovský I, Baňař P, Tuf IH, Hejda M, Konvička M (2010) Spontaneous succession in limestone quarries as an effective restoration tool for endangered arthropods and plants. J Appl Ecol 47:139-147

Walsh C, MacNally R (2003) The hier.part package, version 0.5-1. Hierarchical partitioning. documentation for $\mathrm{R}$ ( $\mathrm{R}$ project for statistical computing). Available at http://cran.r-project.org/. Accessed 5 June 2011

Ward PS (1987) Distribution of the introduced Argentine ant (Iridomyrmex humilis) in natural habitats of the Lower Sacramento Valley and its effects on the indigenous ant fauna. Hilgardia 55:1-16

Zimmermann K, Fric Z, Filipova L, Konvicka M (2005) Adult demography, dispersal and behaviour of Brenthis ino (Lepidoptera: Nymphalidae): how to be a successful wetland butterfly. Eur J Entomol 102:699-706 